\title{
The Implementation of Health Nutrition Services to Improve the Quality of Life among Elderly Poor Family
}

\author{
Diffah Hanim ${ }^{1,2}$ and Anik Lestari ${ }^{2,3}$ \\ $\left\{\right.$ diffah@staff.uns.ac.id $\left.{ }^{1}\right\}$ \\ ${ }^{1}$ Lecturer of Nutrition Science of Medicine Faculty and Postgraduate of Universitas Sebelas \\ Maret, Jl. Ir. Sutami No 36 A, Kentingan, Jebres Surakarta, Indonesia \\ ${ }^{2}$ Public Health Department, Medicine Faculty of Universitas Sebelas Maret, Jl. Ir. Sutami No \\ 36 A, Kentingan, Jebres, Surakarta, Indonesia \\ ${ }^{3}$ Faculty of Medicine of Sebelas Maret University Surakarta, Indonesia
}

\begin{abstract}
This research is an implementation of health nutrition services to improve the quality of life among elderly poor family who have health card/Kartu sehat (KS) from poor family access to nutrition and basic health services. The target of the elderly poor family who have KS ( $\mathrm{n}=288)$. Method: observational analytic with a cross-sectional design. The dependent variables were posyandu support, peer support, the independent variables were healthy behavior and quality of life. The data analyses were Chi-square. Results: Elderly men $(n=136)$ women $(n=152)$. Description of health nutrition services to continuity aspects on average $59.3 \% \mathrm{KS}$ owner who used KS. This condition illustrated of basic health nutrition service component was still very low due to the distance of service location, nutrition service activity, education and community habits, as well as service quality. There were relationship between posyandu support and healthy behavior $(\mathrm{p}=0.336 ; \mathrm{r}=-0.962)$ it means the more elderly aware of healthy living behavior. The relationship between family support and healthy behavior $(\mathrm{p}=0.059 ; \mathrm{r}=-0.471)$ peer support with healthy behavior $(\mathrm{p}=0.001, \mathrm{r}=0.981)$. The implementation of health nutrition services to improve the quality of life among elderly poor family $(p=0.07 ; r=0.14)$. The quality of life among elderly women and elderly men significantly different because of healthy behavior.
\end{abstract}

Keywords: quality of life, support of Posyandu-peer group-family, healthy living

\section{INTRODUCTION}

The target of improving nutrition service on the elderly is supplementation $\mathrm{Ca}$ and vitamin $\mathrm{C}$ which given 4 times in a month or 52 times in a year. Until now there has been no report about healthy living behavior and the quality of life among the elderly in districts and cities of Surakarta. The regions that have nutritional improvement program for improving the quality of life among the elderly is still few with the result of partial research data is not integrated. Nutritional improvement program and healthy living behavior in the poor elderly family group 
obtained from the district and Puskesmas data is still a basic health program. Nutritional improvement program and healthy living behavior supported by Posyandu, peer group socialization and poor family where the elderly life. The data of health services and nutritional elderly at Puskesmas are nutritional status monitoring, blood pressure, and $\mathrm{Hb}$ levels. However, there has not healthy elderly integrated program to stay healthy, means that the quality of life among the elderly to stay active, healthy, and productive has not been analyzed. Therefore, it is necessary to analyze the result of nutritional health service implementation to improve the quality of elderly lieving in a poor family.

\section{METHOD}

The type of experimental research was to implement nutritional health service to improve the quality of life among elderly poor family. Conduct in District of Health in Sragen, Klaten, and Wonogiri working area with multi stage sampling. The target of the elderly poor family and the family who has KS $(n=288)$ men and women with random sampling. Subjects were determined by inclusion and exclusion dependent variables Posyandu support, peer support, and independent variable healthy behavior and the quality of life. The data were analyzed of Chi-square and OR.

\section{RESULT AND DISCUSSION}

The elderly group who did not have KS they had a hard time to access health and nutrition services due to poverty. The target of the elderly poor family and the family who had KS $(n=288)$. The accessibility of poor family to basic health and nutrition services varies greatly between districts. The amount of poor family who bears the elderly in 3 districts in rural areas $(\mathrm{N}=179.867)$, although in some regions where the elderly poor family still have fixed income (retired) there were 132.347 people. The description of utilization aspects of health nutrition services could be seen up to the continuity aspects $59.3 \%$ of KS owner took advantage of it. This condition illustrated that the utilization aspects basic health nutrition services are still low due to the distance of service location, transportation, and communication, nutrition service activity outside of government work hours, education and community habits, as well as the service quality. Different social characteristics in obtaining health nutrition services for improving the quality of life among elderly poor family (Table 1) shows elderly women are more active than elderly men.

Table 1. The description of the different social characteristics in obtaining health nutrition services for improving the quality of life among elderly poor families $(\mathrm{n}=288)$.

\begin{tabular}{lccccc}
\hline \multirow{2}{*}{ Characteristic } & \multicolumn{2}{c}{ Quality of life among the elderly } & Total (n) & $\begin{array}{c}\text { P } \\
\text { Value }\end{array}$ & OR \\
\cline { 2 - 5 } & Good & Less & & & \\
\hline Gender & 79 & 73 & 152 & 0.042 & 0.481 \\
\hline Female & 65 & 71 & 136 & & \\
\hline Male & & & & & \\
\hline Age & 82 & 80 & 162 & 0.032 & 0.570 \\
\hline$\leq 80$ years old & 26 & 21 & 47 & & \\
\hline$>80$ years old & & & & &
\end{tabular}




\begin{tabular}{|c|c|c|c|c|c|}
\hline Family support & & & & & \\
\hline Good & 60 & 63 & 123 & 0.021 & 0.721 \\
\hline Less & 84 & 81 & 165 & & \\
\hline Peer support & & & & & \\
\hline Good & 47 & 43 & 90 & 0.352 & 0.259 \\
\hline Less & 97 & 101 & 198 & & \\
\hline Posyandu support & & & & & \\
\hline Good & 51 & 60 & 111 & 0.166 & 1.188 \\
\hline Less & 93 & 84 & 177 & & \\
\hline Healthy behavior & & & & & \\
\hline Good & 85 & 86 & 171 & 0.140 & 0.904 \\
\hline Less & 59 & 58 & 117 & & \\
\hline income & & & & & \\
\hline Low & 61 & 62 & 123 & 0.007 & 0.956 \\
\hline Middle & 83 & 82 & 165 & & \\
\hline Occupancy & & & & & \\
\hline No job/housewife & 18 & 9 & 27 & 0.033 & 8.705 \\
\hline Labor & 44 & 49 & 93 & & \\
\hline Employee & 48 & 35 & 83 & & \\
\hline Retired Civil Servant/ ARMI & 34 & 51 & 85 & & \\
\hline
\end{tabular}

From table 1 can be known that statistically there was a relationship between quality of life among elderly women and elderly men $(p=0.042)$ with the strengths of weak relationship $(\mathrm{r}=0.481) . \mathrm{m}$ This mean that the elderly subjects on this study have significant differences between the quality of life among elderly women and men. Furthermore, there is a significant relationship between the quality of life among elderly age $\leq 80$ years old with elderly $>$ 80 tahun $(\mathrm{p}=0.032)$ with the strength of a weak relationship $(\mathrm{r}=0.570)$. means that the younger of the elderly age will have better health and nutritional status. This finding in accordance with the study of Aveiro, Driusso, Santos, Kiyoto, and Oishi (2013) who stated that the older the elderly get they will risk of lost appetite so their health and nutrition status decreases as a result of the declining quality of life.

In table 1 it is shown there is a relationship between good family support with the quality of life among elderly statistically significant $(\mathrm{p}=0.021)$ but the strength relationship is weak $(r=0.721)$. this is consistent with the existence of a real elderly income relationship $(p=0.007)$ between middle-income family (Rp 1.800 .000 - Rp 5.000.000 per month) with low-income family $(<\mathrm{Rp} 1.800 .000$ per month) to the quality of life among elderly. The strength of the income elderly family with the quality of life among elderly quite strong $(r=0.956)$. this is in line with the results of Saputri and Indrawati's research (2011).

Table 1 shown that Posyandu support's relationship with the quality of life among elderly statistically was not significant $(\mathrm{p}=0.166)$ but has quite strong relationship, such as; if the elderly do not come to monitor their health and nutritional status at Posyandu will suffer $2 \mathrm{x}$ their quality of life decrease compared with the elderly who monitor their health and 
nutritional status actively at Posyandu $(\mathrm{r}=1.188)$. This is in line with the results of Yuliati, Baroya, and Ririanty's research (2014) which stated there is a difference between the quality of life among elderly who live in a community with elderly social services because the elderly whom live in a family's house will socialize often with the neighbor and peer especially when they meet in monitoring health and nutrition's place. Meanwhile, in this research, the relationship between good peer support with the quality of life among the elderly statistically is not significant $(\mathrm{p}=0.352)$ with the strength relationship is quite weak $(r=0.259)$. If the elderly do not have friends or do not make friends, it is not related to their quality of life. It is related to Yenny and Herwana's finding (2006) which stated that the elderly, especially more than 80 years old do not have peers because many of them have passed away.

This research showed that the elderly who did not work $(9.375 \%)$, as labor $(32.29 \%)$, as an employee (28.81\%) and Civil Servant/ARMY retirement $(33.33 \%)$ had a significant relationship with the quality of life $(p=0.033)$ and the $O R$ as much as 8.705 . means that the more comfortable/established job they had will make their quality of life better, it almost 9x better than the elderly groups who did not have a job or as labor. It is related to Feng, Wenbo, and Rosalin's finding (2016) which stated that the better jobs with adequate income will be more protected from dementia.

The resulting analysis of health nutrition services implementation for improving the quality of life among elderly poor families shown that there is a positive relationship between income level, jobs type, healthy behavior and family support with the quality of life. So that practically there is an agreement to improve private institution (Posyandu, Posbindu, Mosque managers, and other non governmental organization) to work together with medical workers, community leaders, religion leader to facilitate elderly community to make them always behave in a healthy life by relaxed and light exercising which in the end can improve the quality of life. Jobs type and income level are significantly related to improving the quality of life among the elderly. Even though the income was low $(<\mathrm{Rp} 5.000 .000$ per month) it is able to maintain the quality of life among the elderly.

\section{CONCLUSION}

The quality of life among elderly significantly related to income, last jobs type, and family support. In significantly related to healthy behavior (exercise) and age. The quality of life among elderly women and elderly men significantly different because of healthy behavior.

\section{ACKNOWLEDGMENT}

The authors expressed their gratitude to LPPM who had helped with this research fee and Puskesmas at Karanganyar, Sragen, Klaten and Wonogiri working area which had given permission to do the research.

\section{REFERENCES}

[1] M. C. Aveiro, P. Driusso, J. G. dos Santos, V. D. Kiyoto, and J. Oishi, "Effects of a physical therapy program on quality of life among community-dwelling elderly women: randomized-controlled trial," Fisioter. em Mov., vol. 26, no. 3, pp. 503-513, 2013.

[2] L. Herlinah, W. Wiwin, and R. Etty, "Hubungan Dukungan Keluarga dengan Perilaku Lansia dalam Pengendalian Hipertensi," J. Keperawatan Komunitas, vol. 1, no. 2, pp. 108-115, 2013.

[3] W. Jing, R. Willis, and Z. Feng, "Factors influencing quality of life of elderly people 
with dementia and care implications: A systematic review," Arch. Gerontol. Geriatr., vol. 66, pp. 23-41, 2016.

[4] "Gambaran Kesehatan Lanjut Usia di Indonesia," vol. 1, Kementerian Kesehatan RI, Indonesia, 2013.

[5] M. Amelia, W. Saputri, and E. S. Indrawati, "Hubungan Antara Hubungan Sosial Dengan Depresi pada Lanjut Usia,” J. Psikolologi Undip, vol. 9, no. 1, pp. 65-72, 2010.

[6] WHO, "Presentation: 'Designing the road to better health and well-being in Europe' at the 14th European Health forum Gastein," Off. Rec. WHO, no. October, p. 100, 1948.

[7] WHO, "The World Health Organization Quality of Life (WHOQOL)-BREF," no. May. Geneva, Switzerland, pp. 1-7, 2012.

[8] WHO, "Shanghai declaration on promoting health in the 2030 Agenda for Sustainable Development," 2016.

[9] Yenny \& Herwana, "Prevalensi penyakit kronis dan kualitas hidup pada lanjut usia di Jakarta Selatan," Universa Med., vol. 25, no. 4, pp. 164-171, 2006.

[10] A. Yuliati, N. Baroya, and M. Ririanty, "Perbedaan kualitas hidup lansia yang tinggal di komunitas dengan di pelayanan sosial lanjut usia," J. Pustaka Kesehat., vol. 2, no. 1, pp. 87-94, 2014.

[11] D. Bender, INTRODUCTION TO NUTRITION AND METABOLISM, Third edit. London: Taylor \& Francis 11 New Fetter Lane, London EC4P 4EE, 2002.

[12] Z. Gabriel and A. Bowling, "Quality of life from the perspectives of older people," Ageing Soc., vol. 24, no. 5, pp. 675-691, 2004.

[13] M. Gregersen, M. M. Jordansen, and D. L. Gerritsen, "Overall Quality of Life (OQoL) questionnaire in frail elderly: A study of reproducibility and responsiveness of the Depression List (DL)," Arch. Gerontol. Geriatr., vol. 60, no. 1, pp. 22-27, 2015.

[14] Situasi dan Analisis lanjut Usia. Indonesia: Kementerian Kesehatan RI, Pusat Data dan Informasi, 2014.

[15] World Health Organization, WHOQOL User Manual. 2003.

[16] K. Shibuya, H. Hashimoto, and E. Yano, "Individual income, income distribution, and self rated health in Japan: cross sectional analysis of nationally representative sample," $B M J$, vol. 324, pp. 16-19, 2002. 